\title{
The "Hygiene" Hypothesis: repercussions of infectious diseases control programmes
}

\author{
Alberta Bedford Moses ${ }^{1}$ and Dennis Adu-Gyasi ${ }^{2 *}$ \\ ${ }^{1}$ Cape Coast Teaching Hospital, Cape Coast, Ghana \\ ${ }^{2}$ Kintampo Health Research Centre, Box 200, Kintampo North, Ghana
}

\section{The Hygiene Hypothesis}

Immunological studies and evaluations of allergic conditions [1] and even prevalence of certain auto-immune conditions (for example, inflammatory bowel disease) have increased the thinking that higher levels of personal hygiene might results in increased risk of developing allergic diseases $[1,2]$ and reduced immune response to infectious pathogens. This adds to the propaganda that living in extremely clean environment and never exposed to infectious agents to challenge the immune system exposes you to danger when real infections occur [2,3]. This background of hygiene hypothesis formulated in 1989, has been successfully used to the advantage of improving the immune response to infectious agents (for example malaria, bacteria, hookworm) in the form of probiotics; where individuals are exposed to some flora as therapy or supplement to boost the system awaiting eventuality or even in the case of using bolus of hookworm; for a response that will counteract an inflammatory condition $[1,2,4,5]$. Especially on the background that helminth and other parasitic organisms could impact on the gut microbiota to build microbial-metabolite-immune axis that could exert immune-modulatory activity in an indirect manner $[5,6]$. We should not also forget that several studies have shown inverse relationship between microorganism exposure and development of autoimmunity [7]. Coming with this knowledge that after-all, an absolute clean environment could have its detrimental effect, one wonders if some control measures particularly targeting hookworm and other helminths with the intention to eliminate might not come to haunt us in the future with alien conditions that are non-existent in the tropics? It is important to evaluate all possible interactions together with the biological importance of infectious agents to come out with holistic control and preventive measures that are multifaceted $[2,5,8]$.

\section{Immune response and infection}

Naturally, when T-cells are produced, they are schooled in the lymphpoid system to identify and recognize self and non-self-antigens. This presupposes that the more different foreign antigens that one is exposed to help in building a repertoire that will make it easy to mount and immune response [1,9]. In some instances, a previous exposure shortens the duration it takes for an immune response to peak to eliminate an antigen [9]. Exposure to normal bacteria flora in new babies within some hours after birth improved their ability to fight some infections better than those who were allowed to develop their immunity in the natural course [2,10]. In adults, Crohn's disease has been successfully managed by giving bolus of hookworm larvae to affected people [2,7]. Such a beneficial effect from hookworm only supports strongly the hygiene's hypothesis which as mentioned earlier, suggests danger when one lives in an all clean environment $[1,2,7,11]$.
Ascaris lumbricoides infections have been identified to mitigate the fatal effect of cerebral malaria [12]. If such protective potency of a helminth infection could be harnessed, the cerebral malaria menace could be reduced if not completely curbed. The impact of malaria is high among children and even worse in children less than 5 years because of the minimal protective immune response while the repeated exposure to the malaria parasite is known to offer protection in adults in endemic areas [13-15]. These largely support the fact that immune response to a previously exposed antigen facilitates the build-up of protection and for that matter, virtually living in clean environment or getting rid of most infectious agents through control programmes could introduce some alien conditions in regions that hitherto never experienced them $[1,7,16]$.

\section{Region engulfed in "filth" and poverty}

Obviously, there is no dispute about the fact that the African region bear the brunt of infectious diseases, poverty, poor sanitation and what have you [17]. It is therefore good to know that several interventions target this continent to help mitigate the myriad of problems. Use of Insecticide Treated bed Nets (ITNs) and In-door Residual Spraying (IRS) for malaria have been effective though much need to be done towards elimination. The Mass Drug Administration (MDA) of albendazole targets hookworm control, praziquantel targets Schistosoma spp and ivermectin targets parasites of river blindness. What we have failed to do is to comprehensively appreciate the effects of eliminating the infectious agents who might have an advantageous role to play in our ecosystem and biodiversity. The prevalence or recorded cases of inflammatory bowel disease in the African region is nothing compared to the western world $[18,19]$. With the information on the beneficial effect of hookworm exposure, sufferers of such autoimmune conditions might have a remedy.

\section{Repercussions of eliminating infectious agents}

Restricting ourselves to protozoa, for instance hookworm and malaria, the overlap of these infections in the tropical region and endemic areas might be a natural selection to confer protection [1,7]. One then wonders why where those parasites are already prevalent, the key on the agenda is to eliminate than to accommodate and still benefit from their being around? If that observation could be true,

${ }^{\star}$ Correspondence to: Dennis Adu-Gyasi, Cape Coast Teaching Hospital, Cape Coast, Ghana, E-mail: dennis.adu-gyasi@kintampo-hrc.org

Received: November 26, 2018; Accepted: January 22, 2019; Published: January 25,2019 
then managers of helminth and malaria control programmes need to assess the impact of eliminating these organisms together in order not to create an imbalance with unbearable consequential effects $[1,12,20]$.

\section{References}

1. Adkinson F, Stephen H, Bruce B, Robert F, Wesley B, et al. (2014) Allergy Principles and Practice. Middleton (Ed) (Eighth Edn), Elsevier Saunders, USA.

2. Helmby H (2015) Human helminth therapy to treat inflammatory disorders- where do we stand. BMC Immunology 16: 12.

3. Loukas A, Bethony J, Brooker S, Hotez P (2006) Hookworm vaccines: past, present, and future. Lancet Infect Dis 6: 733-741. [Crossref]

4. Strunz EC, Addiss DG, Stocks ME, Ogden S, Utzinger J, et al. (2014) Water, Sanitation, Hygiene, and Soil-Transmitted Helminth Infection: A Systematic Review and MetaAnalysis. PLoS Medicine 11: e1001620.

5. Zaiss M, Rapin A, Lebon L, Dubey L, Mosconi I, et al. (2015) The Intestinal Microbiota Contributes to the Ability of Helminths to Modulate Allergic Inflammation. Immunity 43: 998-1010.

6. Osborne LC, Monticelli A, Nice TJ, Sutherland TE, Siracusa MC, et al (2014) Virus-helminth coinfection reveals a microbiota-independent mechanism of immunomodulation. Science 345: 578-582.

7. Smallwood T, Giacomin P, Loukas A, Mulvenna J, Clark R, et al. (2017) Helminth Immunomodulation in Autoimmune Disease. Front Immunol 8: 453.

8. Anderson R, Medley G (1985) Community control of helminth infections of man by mass and selective chemotherapy. Parasitology 90: 629-660.

9. Abbas A, Lichtman A, Pillai S (2014) Basic immunology: functions and disorders of the immune system. Elsevier Saunders, USA.
10. Rolfe RD (2000) The role of probiotic cultures in the control of gastrointestinal health. J Nutr 130: 396S-402S. [Crossref]

11. Smith J, Brooker S (2010) Impact of hookworm infection and deworming on anaemia in non-pregnant populations: a systematic review. Trop Med Int Health 15: 776-795.

12. Nacher M, Gay F, Singhasivanon P, Krudsood S, Treeprasertsuk D, et al. (2000) Ascaris lumbricoides infection is associated with protection from cerebral malaria. Parasite Immunol 22: 107-113.

13. Sokhna C, Le Hesran JY, Mbaye P, Akiana J, Camara P, et al. (2004) Increase of malaria attacks among children presenting concomitant infection by Schistosoma mansoni in Senegal. Malaria Journal 3: 43.

14. Kinung'hi SM, Magnussen P, Kaatano GM, Kishamawe C, Vennervald BJ (2014) Malaria and Helminth Co-Infections in School and Preschool Children: A CrossSectional Study in Magu District, North-Western Tanzania. PLoS ONE 9: e86510.

15. Njua-Yafi C, Achidi E, Anchang-Kimbi J, Apinjoh T, Mugri R, et al. (2016) Malaria helminths, co-infection and anaemia in a cohort of children from Mutengene, south western Cameroon. Malaria Journal 15: 69

16. Conrad DH (1990) Fc epsilon RII/CD23: the low affinity receptor for IgE. Annu Rev Immunol 8: 623-645. [Crossref]

17. Farmer P (2004) Pathologies of power: Health, human rights, and the new war on the poor. Univ of California Press.

18. Economou M, Pappas G (2008) New global map of Crohn's disease: Genetic environmental, and socioeconomic correlations. Inflamm Bowel Dis 14: 709-720.

19. Hu D, Ren J, Wang G, Gu G, Liu S, et al. (2014) Geographic mapping of Crohn's disease and its relation to affluence in jiangsu province, an eastern coastal province of china. Gastroenterology research and practice 2014: 1-6.

20. Bousquet J, Michel F (1993) In Allergy Principles and Practice. Middleton, Reed, Adkinson, Yunginges, Busse (Eds) 1663: 1059-1076; 1305-1307.

Copyright: (C2019 Moses AB. This is an open-access article distributed under the terms of the Creative Commons Attribution License, which permits unrestricted use, distribution, and reproduction in any medium, provided the original author and source are credited. 